University of Nebraska - Lincoln

DigitalCommons@University of Nebraska - Lincoln

Publications, Agencies and Staff of the U.S.

Department of Commerce

U.S. Department of Commerce

7-1997

\title{
Catches of Humpback and Other Whales from Shore Stations at Moss Landing and Trinidad, California, 1919-1926
}

\author{
Phillip Clapham \\ National Marine Fisheries Service, Southwest Fisheries Science Center \\ Stephen Leatherwood \\ Ocean Park Conservation Foundation, Ocean Park, Aberdeen, Hong Kong \\ Isidore Szczepaniak \\ California Academy of Sciences
}

Robert L. Brownell Jr.

National Marine Fisheries Service, Southwest Fisheries Science Center, rlbcetacea@aol.com

Follow this and additional works at: https://digitalcommons.unl.edu/usdeptcommercepub

Part of the Environmental Sciences Commons

Clapham, Phillip; Leatherwood, Stephen; Szczepaniak, Isidore; and Brownell, Robert L. Jr., "Catches of Humpback and Other Whales from Shore Stations at Moss Landing and Trinidad, California, 1919-1926" (1997). Publications, Agencies and Staff of the U.S. Department of Commerce. 84.

https://digitalcommons.unl.edu/usdeptcommercepub/84

This Article is brought to you for free and open access by the U.S. Department of Commerce at DigitalCommons@University of Nebraska - Lincoln. It has been accepted for inclusion in Publications, Agencies and Staff of the U.S. Department of Commerce by an authorized administrator of DigitalCommons@University of Nebraska - Lincoln. 


\title{
CATCHES OF HUMPBACK AND OTHER WHALES FROM SHORE STATIONS AT MOSS LANDING AND TRINIDAD, CALIFORNIA, 1919-1926
}

\author{
Phillip J. Clapham ${ }^{1}$ \\ National Marine Fisheries Service, Sourhwest Fisheries Science Center, \\ P.O. Box 271, La Jolla, California 92038, U.S.A. \\ STEPHEN LEATHER WOOD ${ }^{2}$ \\ Ocean Park Conservation Foundation, Ocean Park, Aberdeen, Hong Kong
}

ISIDORE SZCZEPANIAK

Departments of Ornithology \& Mammalogy, California Academy of Sciences, Golden Gate Park, San Francisco, California 94118, U.S.A.

Robert L. Browneli, JR.

National Marine Fisheries Service, Southwest Fisheries Science Center, P.O. Box 271, La Jolla, California 92038, U.S.A.

\begin{abstract}
Logbook data from California shore whaling stations at Moss Landing (1919-1922 and 1924) and Trinidad (1920 and 1922-1926) are analyzed. The logs for the two stations record the taking of 2,111 whales, including 1,871 humpbacks, 177 fin whales, 26 sei whales, 3 blue whales, 12 sperm whales, 7 gray whales, 1 right whale, 1 Baird's beaked whale, and 13 whales of unspecified type (probably humpbacks). Most whales were taken from spring to autumn, but catches were made in all months of some years. The sex ratios of humpback, fin, and sei whales (the three species with sufficient sample sizes to test) did not differ from parity. Primary prey, determined from stomach contents, included sardines and euphausiids for both humpback and fin whales, and "plankton" (probably euphausiids) for sei whales. The prevalence of pregnancy was 0.46 among mature female humpbacks and 0.43 among mature female fin whales, although these values are reported with caution. Information on length distribution for all species is summarized. Analysis of the catch data for this and other areas supports the curtent viev that humpback whalcs along the west coast of the continental United States comprise a single feeding stock and also suggests that the present population is well below pre-exploitation levels.

Key words: humpback whale, fin whale, sei whale, North Pacific, whaling, population structure, prey, reproduction, abundance.

${ }^{1}$ Address for correspondence: Smithsonian Institution, NHB 390, MRC 108, Washington,

${ }^{2}$ Posthumous contribution.
\end{abstract} DC 20560, U.S.A. 
Shore whaling along the west coast of North America began with the opening of land stations at Monterey and Crescent City, California, in (or just prior to) 1854 (Starks 1922, Sayers 1984). Operations continued at various locations until the closure of the last of the old-style stations, at Monterey, shortly after the turn of the century (Sayers 1984). Modern shore whaling, involving harpoon cannons mounted on motorized catcher boats, began in British Columbia in 1905 and continued in various places until 1970 (Rice 1974).

During the early period of shore whaling, activities were focused on gray whales (Eschrichtius robustus). However, whalers frequently hunted humpback whales (Megaptera novaeangliae) when the short winter season for the former species was concluded (Sayers 1984). Humpbacks could be taken in Lower (Baja) California during their winter mating and calving season, and again during the months of summer or autumn when they had returned to the waters of "Upper" California to feed. Documentation of this period of whaling is generally poor, and it is not possible to determine the number of humpbacks taken prior to 1900 , or to assess the impact of these catches on the population(s) concerned.

The California Sea Products Company (CSPC) opened a shore whaling station at Moss Landing $\left(36^{\circ} 32^{\prime} \mathrm{N}, 121^{\circ} 53^{\prime} \mathrm{W}\right)$ in 1919 and a second station at Trinidad $\left(41^{\circ} 00^{\prime} \mathrm{N}, 124^{\circ} 10^{\prime} \mathrm{W}\right)$ in 1920 . These two stations, which were the first modern-style operations in California, operated at various times between 1919 and 1926; both operated in the coastal waters of northern and central California and took primarily humpback whales. During this period, detailed catch records were kept, a copy of which has survived in the form of a single $\log$ now preserved at the California Academy of Sciences in San Francisco. The $\log$ provides information on catch composition, sex ratio, length frequencies, stomach contents, body condition, and reproduction. In addition, we have used a copy of the Trinidad station's original logbook for the year 1922, which lists weather conditions, catcher activity, and whales taken. Here, we present the results of an analysis of these data and consider the impact of the Moss Landing and Trinidad catches on the humpback whale population that feeds along the west coast of North America.

\section{Methods and Materials}

\section{CSPC LOG}

The CSPC log entries are written in a single hand, probably that of Barton Warren Evermann. Evermann was at the California Academy of Sciences in the 1920s, and it is known that CSPC personnel gave him "a complete tally of whales taken" at the end of each season (field notes of Lawrence M. Huey; see Howell and Huey 1927, 1930). It is likely that the information summarized by Evermann in the log underwent at least two transcriptions from the original data: one from original notes taken (presumably by station managers) during processing at the stations, and probably a second from whatever summary was provided to Evermann by CSPC. With the exception of the 1922 
Trinidad $\log$ mentioned below, the fate of the original records is unknown. Basic information contained in the logs includes date, species, sex, and station. In addition, the following variables are recorded:

Area taken - The log gives a total of 26 areas in which whales were caught. All are geographic locations or hydrographic features (e.g., Half Moon Bay, Rocky Point, Kedd Rock). We have not attempted to analyze any trends in location of catch, since the data are of variable quality and consistency. In particular, all of the animals processed at Trinidad are listed as having been taken in "Trinidad"; similarly, the location of take for all of the early catches processed at Moss Landing is listed simply as "Moss Landing."

Length and weight-As noted below, it is clear from analysis of the length frequency data that many lengths were visually estimated; thus the value of this information is limited. Because the weighing of a whale involves considerably more effort than measuring its length, we have assumed that all weights were estimated. Since weight is also much less easily ground-truthed than length, we regard all weight data as highly unreliable and have made no attempt to use them in analyses.

Stomach contents - Items listed as stomach contents include various species of fish, as well as the generic term "fish" (presumably reflecting material that was sufficiently well digested to preclude specific identification). In addition, the term "shrimp" is frequently used; we have assumed that this is synonymous with euphausiids of one or more species, as is indicated from contemporary observations made at Trinidad by Howell and Huey (1930). "Empty" (or the whalers' abbreviation "M.T.") is also used, as well as "milk" and a variety of other items such as "octopus" (presumably squid), and "plankton." The meaning of the latter term is unclear. At face value it might appear to refer to calanoid copepods; however, there is good reason to believe that it was actually another word for euphausiids, perhaps used by different inspectors. All of the records of "plankton" come from Trinidad in 1926, and the singular use of either this term or shrimp (rather than both) is consistent in the log over periods of weeks. There is only one day (11 July 1926) when both words appear. Both are used for single entries (two fin whales) that day; the record of plankton comes at the end of a seven-week period when only this word appears, while the noting of shrimp begins a stretch of six weeks when plankton is not mentioned at all. The belief that the whalers used the two terms interchangeably for euphausiids is supported indirectly by Rice (1977, table 3), who found almost no evidence of copepods as prey in California baleen whales. Similarly, the designation in the Moss Landing and Trinidad log of "whale food" is probably krill, but we have classified it here as "other," a category which includes anything that is not anchovies (Engraulis mordax), fish, herring (Clupea pallasi), milk, plankton, shrimp, sardines (Sardinops sagax), or empty.

Reproductive condition-For females the presence or absence of an "embryo" (fetus) is recorded. In addition, the log records whether or not the female had a calf. As discussed below, there are problems with the reliability of both of these variables. Apparent pregnancy rates were calculated for humpback and 
fin (Balaenoptera physalus) whales; sample sizes for other species were insufficient for analysis.

Body condition-The general body condition (presumably a general assessment of blubber thickness) of cach whale was subjectively assessed in the log. The five common designations are poor, fair, good, very good, and excellent; there are some other notations, such as "good oil producer." Since the five basic assessments are so subjective, we have largely ignored body condition in our analyses, although a simple exploratory investigation of the change in average condition over the year was conducted for humpback whales.

\section{Trinidad Station Log}

A logbook preserved by the Trinidad Museum Society gives details of weather, catcher-boat activity (number of trips per day, idle time due to need for coaling or repaits, etc.), and number of whales caught and processed at Trinidad, for the period 15 May to 25 November 1922. We compared the information on catches with that given in the CSPC log, and in addition we used the former to give a basic description of catcher effort during this period. The Trinidad station $\log$ does not list other details (e.g., length, stomach contents, etc.) of the whales taken.

\section{Results}

According to the CSPC, $\log$ a total of 2,094 whales were landed at the Moss Landing and Trinidad stations between 1919 and 1926. The 1922 station $\log$ from Trinidad lists an additional 4 humpback whales (two of which were killed but lost to bad weather) and 13 of unspecified type taken that year that do not appear in the CSPC $\log$. Given that all but two of the whales taken at Trinidad in that year were humpbacks, the "unspecified" animals were almost certainly of this species, but we have not included them in the humpback totals. Taking these additions into account, the adjusted total carch for the entire period is 2,111 . We note that the CSPC $\log$ for 1922 contains three humpback whales that for some reason are not recorded in the Trinidad station log; therefore, neither log can be considered error-free.

The total number of whales killed in each year are shown by species in Figure 1 . Humpback whales $(n=1,871)$ constituted the majority of the catch both overall and in all years except 1926 , when the predominant species were fin and sei (Balaenoptera borealis) whales. Total catches peaked at 528 in 1922. There is no information in the CSPC log on the number of whales that were struck and lost. Only two cases appear in the Trinidad 1922 station log; these are the two whales mentioned above, which were killed but lost in rough weather.

Years of operation, dates of furst and last catches within each year, and the number of catch days each month for each station ate summarized in Table 1. Catches are recorded for Moss Landing from 1919 to 1924, with the exception of 1923 , for which there is no record of the station's operation. It is known 


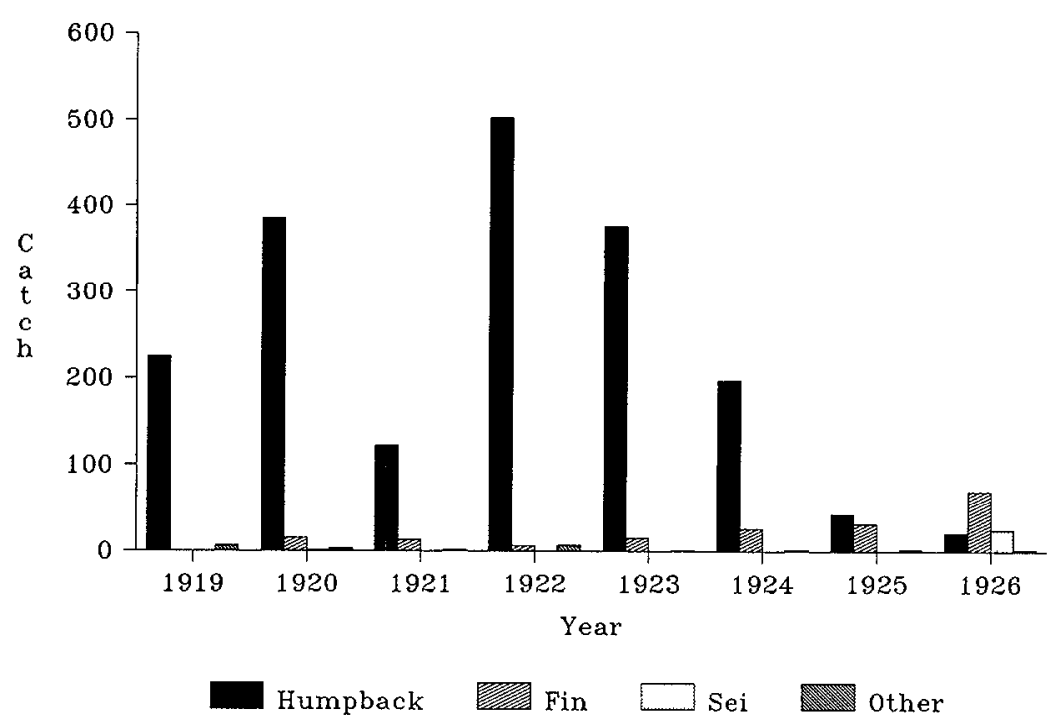

Figure 1. Total catch recorded at Moss Landing and Trinidad, 1919-1926, by species. Not included are 13 whales of unspecified type (probably humpbacks) raken at Trinidad in 1922.

that Moss Landing operated sporadically in the spring and late autumn of 1925, a year that was marked by continual bad weather (Anon. 1926), but for unknown reasons the log does not reflect this. A total of 971 whales were taken at Moss Landing; these are summarized by species and year in Table 2. Trinidad became operational in September 1920 but was closed for all of 1921, which was a "poor market" year for whale products (Scheffer and Slipp 1948). Catches resumed in 1922 and continued until the end of the fishery in September 1926. A total of 1,140 whales was processed at Trinidad; these are summarized by species and year in Table 3 .

Some of the totals derived from the log do not match those given by Kel$\log$ (1931) and Radcliffe (1933). Most of the discrepancies are trivial and probably result from minor errors of transcription or addition (it is likely that both authors used the same sources). Two are quite large. The first is our total of 502 humpbacks taken in 1922 vs. 600 in both Kellogg and Radcliffe. Since the CSPC log (which may well have been one of the sources for these two authors) lists 500 humpbacks for 1922, and since the difference between this figure and the 600 quoted by Kellogg and Radcliffe is exactly 100 animals, we suggest that the 600 represents a simple mistake in copying or addition (the 1922 total of 502 animals reported here is likely accurate, since it is based upon individual records from the Trinidad station log). The second discrepancy is harder to explain. Our total for humpbacks taken in 1923 is 376, which is very different from the 792 reported by Kellogg and Radcliffe. We are unable to explain this major discrepancy, unless Moss Landing did indeed operate during 1923 and caught 416 humpbacks. However, there is no record of Moss Landing being open in this year; furthermore, as noted by Rice (personal 
Table 1. Dates of operation and number of days on which whales were caught at Moss Landing (ML) and Trinidad (TR) stations.

\begin{tabular}{|c|c|c|c|c|c|c|c|c|c|c|c|c|c|c|c|c|}
\hline \multirow[b]{2}{*}{ Year } & \multirow[b]{2}{*}{ Stat } & \multicolumn{2}{|c|}{ Catch dates } & \multicolumn{12}{|c|}{ Number of days on which catches were made } & \multirow[b]{2}{*}{ Total } \\
\hline & & First & Last & Jan & Feb & Mar & Apr & May & Jun & Jul & Aug & Sep & Oct & Nov & Dec & \\
\hline 1919 & ML & $21 \mathrm{Jan}$ & $28 \mathrm{Dec}$ & 1 & 1 & 4 & 16 & 13 & 15 & 15 & 11 & 20 & 22 & 20 & 8 & 146 \\
\hline \multirow{2}{*}{1920} & $\mathrm{ML}$ & 5 Jan & $27 \mathrm{Dec}$ & 5 & 11 & 17 & 13 & 23 & 22 & 25 & 22 & 22 & 17 & 22 & 8 & 207 \\
\hline & TR & 9 Sep & 13 Nov & & & & & & & & & 12 & 20 & 5 & & 37 \\
\hline 1921 & ML & $1 \mathrm{Jan}$ & $30 \mathrm{Dec}$ & 6 & & & & & 7 & 10 & 15 & 12 & 17 & 13 & 12 & 92 \\
\hline \multirow[t]{2}{*}{1922} & ML & $3 \mathrm{Jan}$ & 24 Sep & 11 & 8 & 12 & 11 & 21 & 18 & 13 & 10 & 1 & & & & 105 \\
\hline & TR & ? Apr & $25 \mathrm{Nov}$ & & & & $2 ?$ & 12 & 19 & 29 & 29 & 21 & 24 & 17 & & 153 \\
\hline 1923 & TR & $7 \mathrm{Apr}$ & $31 \mathrm{Oct}$ & & & & 14 & 27 & 26 & 24 & 23 & 14 & 8 & & & 136 \\
\hline \multirow[t]{2}{*}{1924} & $\mathrm{ML}$ & $4 \mathrm{Apr}$ & $26 \mathrm{Nov}$ & & & & 13 & 9 & 12 & 6 & & & 3 & 10 & & 53 \\
\hline & TR & $14 \mathrm{Apr}$ & $24 \mathrm{Oct}$ & & & & 11 & 20 & 22 & 15 & 12 & 6 & 9 & & & 95 \\
\hline 1925 & I'R & 6 May & 3 Oct & & & & & 8 & 11 & 10 & 10 & 15 & 2 & & & 56 \\
\hline 1926 & TR & 20 May & $30 \mathrm{Sep}$ & & & & & 10 & 11 & 18 & 12 & 18 & & & & 69 \\
\hline Station & ML & - & - & 23 & 20 & 33 & 53 & 66 & 74 & 69 & 58 & 55 & 59 & 65 & 28 & 603 \\
\hline totals & TR & & & 0 & 0 & 0 & 27 & 77 & 89 & 96 & 86 & 86 & 63 & 22 & & 546 \\
\hline Total & - & - & - & 23 & 20 & 33 & 80 & 113 & 163 & 165 & 144 & 141 & 122 & 87 & 28 & 1,149 \\
\hline
\end{tabular}


Table 2. Total catches at Moss Landing, 1919-1924, by species.

\begin{tabular}{lrrrrrrr}
\hline \hline Species & 1919 & 1920 & 1921 & 1922 & 1923 & 1924 & Total \\
\hline Humplack & 225 & 338 & 122 & 154 & & 76 & 915 \\
Fin & & 15 & 13 & 5 & & 5 & 38 \\
Sei & 2 & 1 & & & & & 1 \\
Blue & 4 & 1 & 1 & 1 & & & 2 \\
Sperm & & & 1 & 5 & & & 6 \\
Gray & & 1 & & & & 1 & 1 \\
Right & & & & & & \\
Bottlenose & 231 & 356 & 137 & 165 & 0 & 82 & 971 \\
Total & & & & & & & \\
\hline
\end{tabular}

communication), it is difficult to believe that the three or four catcher boats operating from Moss Landing could have caught so many whales in one year. Pending review of local newspaper archives, this discrepancy remains unresolved.

\section{Catcher Effort, Trinidad 1922}

Detailed records in the Trinidad station log for 1922 begin on 15 May; the $\log$ notes that 12 whales had been taken ptior to this, including two in April (date and species not given). One steam-powered catcher, the Hawk, operated from the beginning of the season until 11 November, when the $\log$ records that it departed for San Francisco and thence to resume work at the company's Moss Landing station. A second steam catcher, the Port Saunders, arrived at Trinidad on 2 July; this vessel began work on 5 July and continued until the season closed on 25 November.

Effort for the two catchers for the period 15 May to 25 November is summarized in Table 4 . Each vessel made between one and (rarely) three trips per day, suggesting that their range of operation was relatively local; overnight trips are rarely recorded. Hawk and Port Saunders had a similar catch rate of approximately 1.3 whales per day, or one per trip. A total of 12 complete days

Table 3. Total catches at Trinidad, 1920-1926, by species. The 13 "unspecified" whales taken in 1922 were almost certainly humpbacks.

\begin{tabular}{lcrrrrrrr}
\hline \multicolumn{1}{c}{ Species } & 1920 & 1921 & 1922 & 1923 & 1924 & 1925 & 1926 & Total \\
\hline Humpback & 47 & & 348 & 376 & 121 & 43 & 21 & 956 \\
Fin & & & 1 & 15 & 21 & 32 & 70 & 139 \\
Sei & & & & & & & 25 & 25 \\
Blue & & & 1 & 1 & 1 & 2 & 1 & 5 \\
Sperm & & & & & & & 1 & 1 \\
Gray & & & 13 & & & & 118 & 1,140 \\
Unspecified & 47 & 0 & 363 & 392 & 143 & 77 & 13 \\
Total & 4 & & & & & & & \\
\hline
\end{tabular}


Table 4. Effort and take for the Trinidad station's two steam-powered catchers Hauk and Port Saunders, 15 May-25 November 1922.

\begin{tabular}{lcc}
\hline & Hawk & Port Saunders \\
\hline Days worked & 141 & 124 \\
Trips made & 163 & 166 \\
Days lost to coaling or repair/maintenance & 20 & 13 \\
Whales caught & 183 & 167 \\
Whales/day & 1.3 & 1.3 \\
Whales/trip & 1.1 & 1.0 \\
\hline
\end{tabular}

(and several more partial days) were lost to bad weather (either dense fog or high seas) over the season. Fog was frequent, being recorded for parts or all of $53 \mathrm{~d}$. Of $81 \mathrm{~d}$ on which wind velocity was subjectively recorded, four were calm, 52 "light", 12 "moderate", 12 "strong", and one was given as "gale." The prevailing wind was northwest.

Various comments are recorded in the log, including frequent remarks about whales being "plentiful but wild" (i.e., evasive and difficult to catch).

\section{HUMPBACK WiIALES}

Timing of catches-A total of 1,871 humpback whales were killed, 915 by Moss Landing and 956 by Trinidad. Humpbacks were taken in every month of the year. The smallest catches were in January and February (20 and 29 whales, respectively). The number of whales taken rose in spring and peaked during May, June, and July (293, 298, and 301, respectively). The stations continued to kill substantial numbers of animals through November; in December, only 39 animals were taken. Catches are broken down by month and year in Table 5. Because effort data are not available, it is not clear whether the considerable interannual variation in catches for certain months is a function of differences in search effort, weather, or local abundance of whales. For example, the number of humpbacks taken in July and August of 1922 was notably larger than in the same months of other years.

Irrespective of effort, the number of whales taken during the winter months of some years is noteworthy. A catch of 19 humpbacks in February of 1920 (caught on $11 \mathrm{~d}$, primarily in the latter half of the month) is of particular interest. Of the 49 whales killed in January and February, sex was recorded for 24: 11 were female, 13 male. The stomachs of 22 humpbacks taken during these months were examined: $9(40.9 \%)$ were empty, and all but one of the remaining 13 contained sardines. Reported lengths (see caveat below) ranged from 30 to $55 \mathrm{fr}$ (mean $=42.0, \mathrm{SD}=6.75, n=24$ whales).

Length frequencies-From a graphical summary of humpback whale length frequencies (Fig. 2), it is immediately obvious that many of the reported lengths represent visual estimates rather than actual measurements (note the sharp peaks every five feet, and the particular preponderance of 45 -ft animals). Examination of the data by year and by station suggests that the only consis- 
Table 5. Humpback whale catches by month and year for Moss Landing (MJ) and Trinidad (TR).

\begin{tabular}{|c|c|c|c|c|c|c|c|c|c|c|}
\hline Month & Station & 1919 & 1920 & 1921 & 1922 & 1923 & 1924 & 1925 & 1926 & $\begin{array}{c}\text { Total } \\
\text { (TR + } \\
\text { ML) }\end{array}$ \\
\hline January & $\begin{array}{l}\mathrm{ML} \\
\mathrm{TR}\end{array}$ & & 5 & 5 & 10 & & & & & 20 \\
\hline February & $\begin{array}{l}\text { ML } \\
\text { TR }\end{array}$ & 1 & 19 & & 9 & & & & & 29 \\
\hline March & $\begin{array}{l}\text { ML } \\
\text { TR }\end{array}$ & 6 & 25 & & 20 & & & & & 51 \\
\hline April & $\begin{array}{l}\mathrm{ML} \\
\mathrm{TR}\end{array}$ & 25 & 21 & & 14 & 27 & $\begin{array}{l}20 \\
12\end{array}$ & & & 119 \\
\hline May & $\begin{array}{l}\text { ML } \\
\text { TR }\end{array}$ & 18 & 48 & & $\begin{array}{l}40 \\
17\end{array}$ & 112 & $\begin{array}{l}11 \\
28\end{array}$ & 11 & 8 & 293 \\
\hline June & $\begin{array}{l}\text { ML } \\
\text { TR }\end{array}$ & 24 & 41 & 6 & $\begin{array}{l}33 \\
34\end{array}$ & 97 & $\begin{array}{l}14 \\
32\end{array}$ & 12 & 5 & 298 \\
\hline July & $\begin{array}{l}\text { ML } \\
\text { TR }\end{array}$ & 22 & 42 & 19 & $\begin{array}{l}16 \\
90\end{array}$ & 68 & $\begin{array}{r}5 \\
25\end{array}$ & 8 & 6 & 301 \\
\hline August & $\begin{array}{l}\text { ML } \\
\text { TR }\end{array}$ & 15 & 38 & 17 & $\begin{array}{l}12 \\
93\end{array}$ & 35 & 12 & 7 & & 229 \\
\hline September & $\begin{array}{l}\text { ML } \\
\text { TR }\end{array}$ & 33 & $\begin{array}{l}28 \\
16\end{array}$ & 14 & 47 & 21 & 3 & 5 & 2 & 169 \\
\hline October & $\begin{array}{l}\text { ML } \\
\text { TR }\end{array}$ & 32 & $\begin{array}{l}29 \\
25\end{array}$ & 24 & 42 & 16 & $\begin{array}{l}3 \\
9\end{array}$ & & & 180 \\
\hline November & $\begin{array}{l}\text { ML } \\
\text { TR }\end{array}$ & 35 & $\begin{array}{r}34 \\
6\end{array}$ & 20 & 25 & & 23 & & & 143 \\
\hline December & $\begin{array}{l}\text { ML } \\
\text { TR }\end{array}$ & 14 & 8 & 17 & & & & & & 39 \\
\hline Total & Both & 225 & 385 & 122 & 502 & 376 & 197 & 43 & 21 & 1,871 \\
\hline
\end{tabular}

tently measured lengths come from Trinidad during its first brief season of operation in the autumn of 1920 (Fig. 3). While the distribution of these lengths $(n=47)$ appears less artificial than that of the overall sample, we cannot determine conclusively whether the lengths of the animals concerned were measured or estimated.

Although the problems with the length data preclude their use in many respects, the information is not devoid of value. For the purpose of certain analyses, we make the assumption that the reported lengths were either measured, or estimated to within a few feet of actual length, and thus provide a reasonable indication of size. That the length data reported below for humpback, fin, and sei whales consistently show the reverse sexual size dimorphism characteristic of these species (Ralls 1976) supports the belief that the information is generally reliable. However, we caution that this may not be the case, and all relevant results are reported below with this caveat in mind.

Length was recorded for 1,593 humpback whales. The CSPC log lists a female "humpback" of "75 feet" in 1922, but the Trinidad station log unequivocally states that this animal was a fin whale. The greatest length re- 


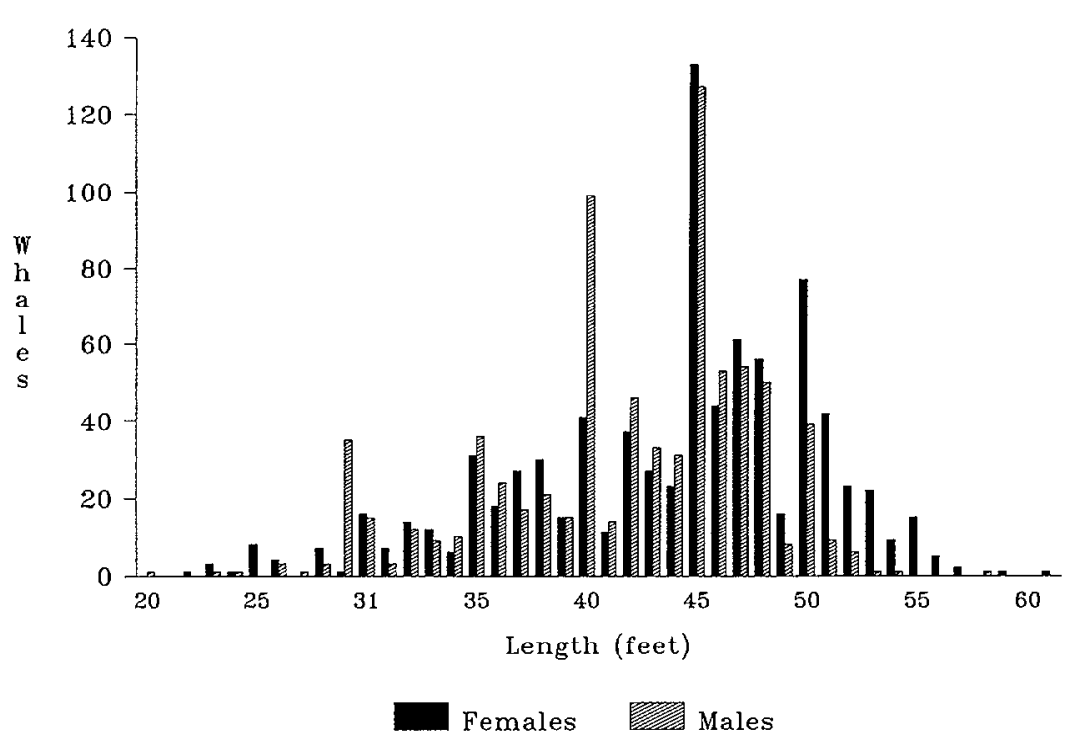

Figure 2. Length frequencies recorded for humpback whales at Moss Landing and Trinidad, 1919-1926.

corded for a humpback is $61 \mathrm{ft}$. This whale was female, as were 197 (77.9\%) of the 253 whales reported as $50 \mathrm{ft}$ or more (Fig. 2). The mean length for all females was $43.9 \mathrm{ft}(\mathrm{SD}=6.76, n=847)$, and for all males $42.4 \mathrm{ft}(\mathrm{SD}=$ $5.43, n=746$ ).

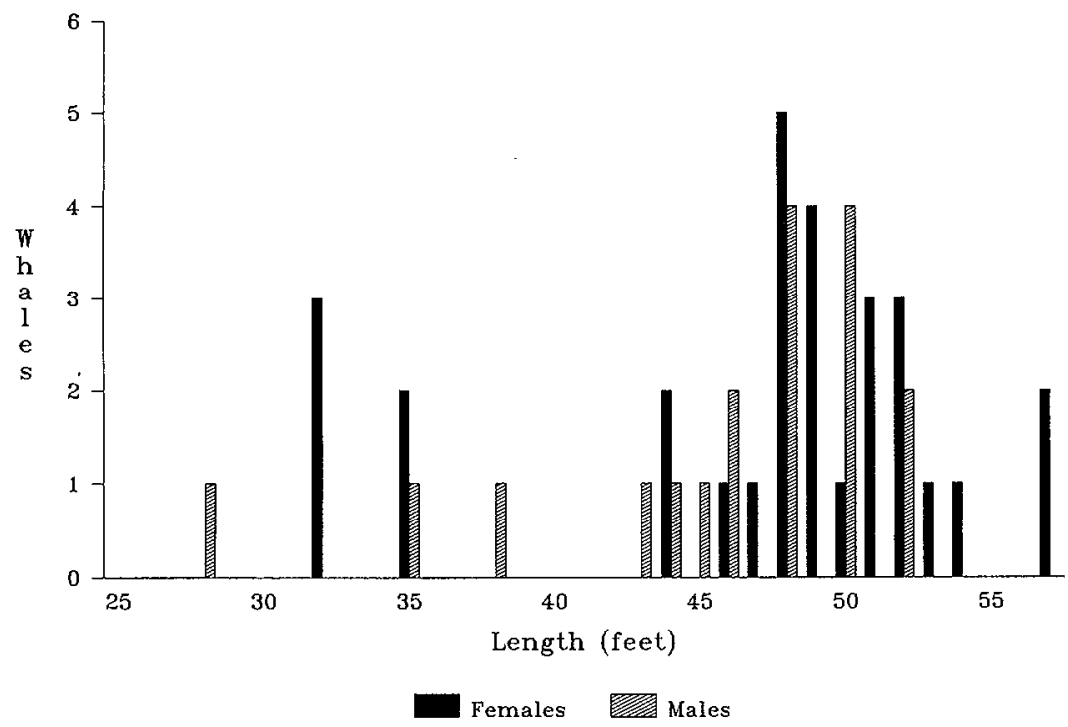

Figure 3. Length frequencies recorded for humpback whales at Trinidad only, in 1920. 
Table 6. Recorded stomach contents for humpback, fin, and sei whales taken at Moss Landing and Trinidad, 1919-1926.

\begin{tabular}{lccr}
\hline Stomach contents & Humpback & Fin & Sei \\
\hline Empty & 187 & 28 & 4 \\
Anchovies & 54 & & \\
Unidentified fish & 27 & & \\
Herring & 19 & 1 & \\
Milk & 35 & 92 & 17 \\
Shrimp & 555 & 15 & 5 \\
Sardines & 626 & & \\
Shrimp and sardines & 10 & 3 & 26 \\
Other & 29 & 169 & \\
Total & 1,542 & & \\
\hline
\end{tabular}

Note: "plankton" (included here under "shrimp") was recorded in the stomachs of 8 humpbacks, 31 fin whales and 16 sei whales.

Mean lengths for each year remained relatively constant until 1926, when a small decline is apparent. Averages for each year were: $1920(43.3 \mathrm{ft}, \mathrm{SD}=$ $6.51, n=336), 1921(42.9 \mathrm{ft}, \mathrm{SD}=6.96, n=122), 1922(43.0 \mathrm{ft}, \mathrm{SD}=$ $6.47, n=498), 1923(43.9 \mathrm{ft}, \mathrm{SD}=5.90, n=376), 1924(43.0 \mathrm{ft}, \mathrm{SD}=$ $4.99, n=197), 1925(43.1 \mathrm{ft}, \mathrm{SD}=5.53, n=43)$, and $1926(38.5 \mathrm{ft}, \mathrm{SD}$ $=5.35, n=21$ ).

Sex ratio-The sex was recorded of 1,593 humpback whales, of which 847 $(53.2 \%)$ were female and $746(46.8 \%)$ were male. Although the observed sex ratio in this overall sample is not quite different from parity, the difference is close to significance $\left(\chi^{2}=3.204, P<0.1\right.$, $\left.\mathrm{df}=1\right)$. Additional analyses show that statistically even sex ratios were observed in all months of the year.

Stomach contents-Stomach contents were recorded for 1,542 humpbacks. Results are summarized for humpback, fin, and sei whales in Table 6, and for humpback whales by year in Table 7. For humpbacks, euphausiids (shrimp) and sardines were the most common items reported. There was considerable variation between years in both predominant prey type and the percentage of

Table 7. Humpback whale stomach contents, by year (Moss Landing and Trinidad combined).

\begin{tabular}{|c|c|c|c|c|c|c|c|c|}
\hline \multirow[b]{3}{*}{ Year } & \multicolumn{3}{|c|}{ Stomachs } & \multirow{2}{*}{\multicolumn{5}{|c|}{ Contents (\% of all stomachs with prey) }} \\
\hline & \multirow[b]{2}{*}{ Total } & \multirow{2}{*}{$\%$ empty } & \multirow{2}{*}{$\begin{array}{c}\% \text { with } \\
\text { prey }\end{array}$} & & & & & \\
\hline & & & & Shrimp & Sardine & Anchovy & Herring & Other \\
\hline 1920 & 310 & 18.4 & 81.6 & 0.8 & 58.1 & 21.3 & 7.3 & 12.6 \\
\hline 1921 & 102 & 34.3 & 65.7 & 0.0 & 76.1 & & & 23.9 \\
\hline 1922 & 473 & 11.0 & 89.0 & 39.4 & 58.2 & & 2.3 & 2.1 \\
\hline 1923 & 366 & 2.7 & 97.3 & 82.3 & 16.9 & & & 0.8 \\
\hline 1924 & 194 & 14.4 & 85.6 & 41.0 & 58.4 & & & 0.6 \\
\hline 1925 & 42 & 4.8 & 95.2 & 42.5 & 45.0 & & & 12.5 \\
\hline 1926 & 20 & 15.0 & 85.0 & 52.9 & 47.1 & & & 0 \\
\hline
\end{tabular}




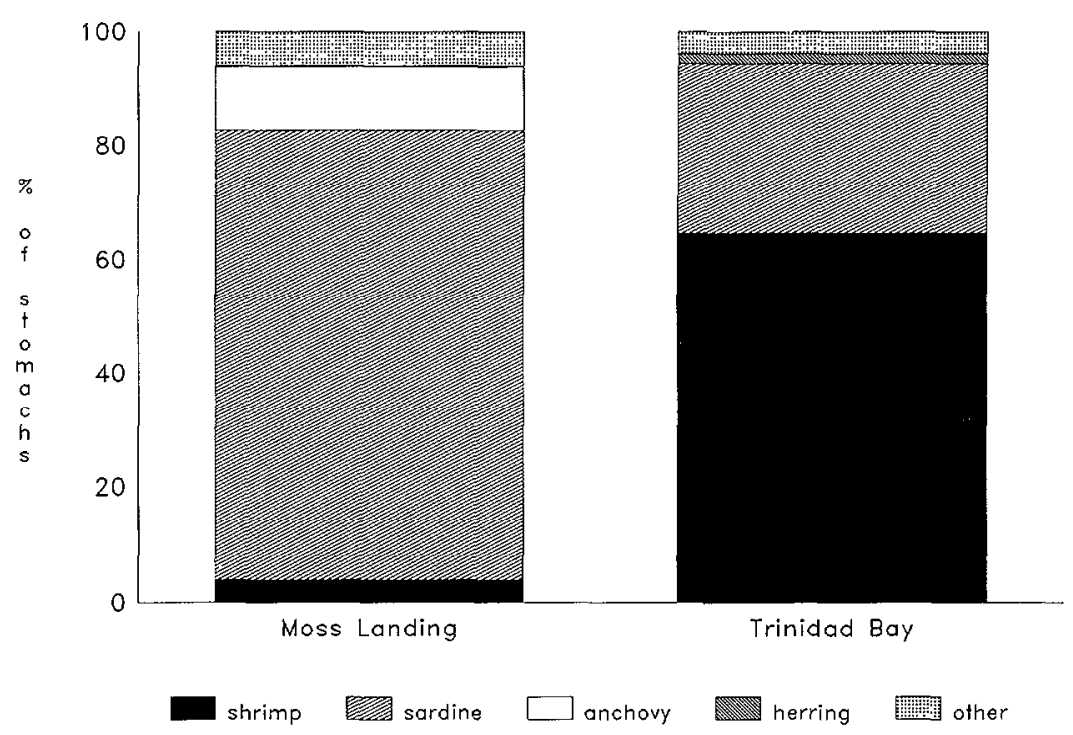

Figure 4. Prey type, by area, recorded from stomach contents of humpback, fin, and sei whales.

whales with empty stomachs. The latter ranged from a minimum of $2.7 \%$ of 366 stomachs in 1923 to a maximum of $34.3 \%$ of 102 stomachs in 1921. Prey composition for humpback, fin, and sei whales, by station, is shown in Figure 4.

Reproduction-Calculation from the data of the proportion of females that was pregnant is complicated by two factors. First, it is unlikely that examinations were conducted on all females or with the consistent thoroughness that would minimize the possibility that a small fetus would escape detection. Thus, calculated figures almost certainly represent minimum apparent values for the population. Second, pregnancy values can be calculated only as a percentage of all sexually mature females, yet our only correlate of maturity is body length, a variable whose measurement in these data is imprecise. If we examine the apparent prevalence of pregnancy among females of different approximate lengths (Fig. 5), the values increase sharply with length to $46 \mathrm{ft}$, then appear to level off. In light of this we have taken $46 \mathrm{ft}$ as the minimum length at which all female humpbacks are likely to be sexually mature (this assumption is supported by Rice's (personal communication) observation that all females of more than $45 \mathrm{ft}$ examined by him off California in later years were mature). The apparent prevalence of pregnancy among females of this length or greater was 0.46 (172 of 374 whales). Of the 374 female humpbacks longer than $45 \mathrm{ft}, 38$ were recorded as being accompanied by a first-year calf. Only one (2.6\%) of the 38 mothers concerned was reported as pregnant.

Body condition-The log's five primary categories for body condition, which ranged from excellent to poor, were transformed into numerical ratings of from 


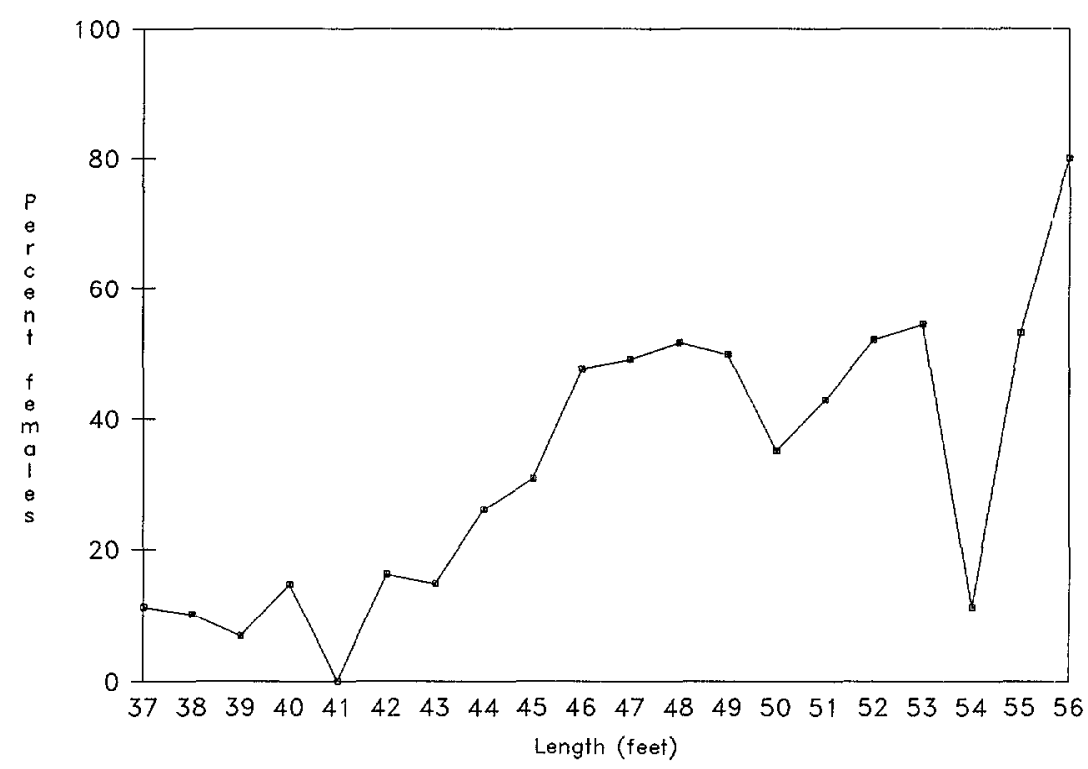

Figure 5. The percentage of female humpbacks recorded as pregnant, by length. Data are from both Moss Landing and Trinidad.

1 to 5, respectively (any other categorization was ignored). Using this scale, changes in condition over the year were investigated by examining the number of animals in each category per three-month period (January-March, AprilJune, July-September, and October-December). Although the assessments are undoubtedly subjective, there was a significant change in condition over the year $\left(\chi^{2}=73.197, \mathrm{df}=6, P<0.001, n=1,729\right.$ humpbacks $)$. Mean body condition was poorest in March (3.25, SD $=0.54, n=20)$ and rose through the summer to a peak in October $(2.43, \mathrm{SD}=0.64, n=120)$.

\section{Fin Whales}

A total of 177 fin whales was taken (38 from Moss Landing, 139 from Trinidad). The majority (102) were killed in 1925 and 1926, when humpback catches were in decline. Fin whales were caught in every month of the year except March (Table 8 ), with the majority (142, or $80.2 \%$ of the total) being taken between June and September. Of the 177 fin whales, 85 (48.0\%) were female, and $92(52.0 \%)$ male, a sex ratio that does not deviate significantly from parity $\left(\chi^{2}=0.23\right.$, $\left.\mathrm{df}=1, \alpha=0.05\right)$.

Lengths are given in the log for all 177 fin whales. Interestingly, and with the exception of a peak at $70 \mathrm{ft}$ for females, length frequencies for this species (Fig. 6) do not show the marked artificial distribution found with humploacks (compare Fig. 2), suggesting that most of the animals may actually have been measured. The mean length for females was $64.2 \mathrm{ft}(\mathrm{SD}=7.32$, range $=48-$ 
Table 8. Catches of other species by month, 1919-1926, for Moss Landing (ML) and Trinidad (TR).

\begin{tabular}{|c|c|c|c|c|c|c|c|c|c|c|c|}
\hline \multirow[b]{2}{*}{ Month } & \multicolumn{2}{|c|}{ Fin whale } & \multicolumn{2}{|c|}{ Sei whale } & \multicolumn{2}{|c|}{ Blue whale } & \multicolumn{2}{|c|}{ Sperm whale } & \multicolumn{2}{|c|}{ Gray whale } & \multirow[b]{2}{*}{ Total } \\
\hline & ML & TR & ML & TR & ML & TR & ML & TR & ML & TR & \\
\hline January & 3 & & & & & & 2 & & 6 & & 11 \\
\hline February & 1 & & & & & & & & & & 1 \\
\hline March & & & & & & & & & & & \\
\hline April & 1 & 1 & & & & & 1 & & & & 3 \\
\hline May & 1 & 6 & & & & & & 1 & & & 8 \\
\hline June & 3 & 21 & & & & & & & & & 24 \\
\hline July & 3 & 46 & & & 2 & 1 & 1 & & & 1 & 54 \\
\hline August & 2 & 28 & & 2 & & & & 2 & & & 34 \\
\hline September & 6 & 32 & 1 & 23 & & & 1 & 1 & & & 64 \\
\hline October & 7 & 4 & & & & & 1 & 1 & & & 13 \\
\hline November & 8 & & & & & & 1 & & & & 9 \\
\hline December & 3 & & & & & & & & & & 3 \\
\hline Total & 38 & 138 & 1 & 25 & 2 & 1 & 7 & 5 & 6 & 1 & 224 \\
\hline
\end{tabular}

$81 \mathrm{ft}, n=84)$, and for males $60.8 \mathrm{ft}(\mathrm{SD}=6.14$, range $=46-75 \mathrm{ft}, n=$ 92).

Stomach contents were recorded for 169 fin whales (Table 6). Of these, 28 (16.6\%) were empty. The predominant prey items in the 141 remaining whales were shrimp (61 whales, or $43.3 \%)$ and sardines $(45$, or $31.9 \%)$. "Plankton" was recorded in 31 stomachs (22.0\%).

Taking $65 \mathrm{ft}$ as the minimum length at which all female fin whales are

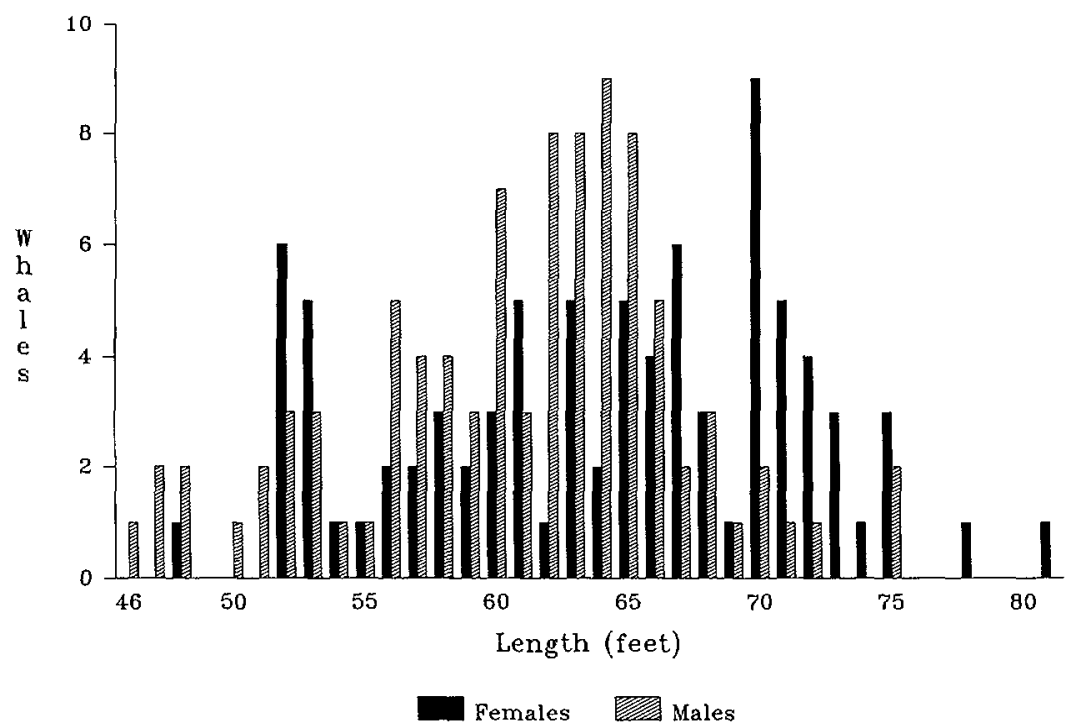

Figure 6. Length frequencies recorded for fin whales at Moss Landing and Trinidad. 
likely to be sexually mature, the apparent prevalence of pregnancy among animals of this size or larger was 0.43 (20 of 46 females).

\section{SEI Whales}

Twenty-six sei whales were killed, all but one in 1926. All but two (taken in August) were caught in September (Table 8). The observed sex ratio of 16 females to 10 males does not differ significantly from parity $\left(\chi^{2}=0.70\right.$, df $=1, \alpha=0.05)$. The mean length for females was $46.1 \mathrm{ft}(\mathrm{SD}=5.0$, range $=30-50 \mathrm{ft}, n=16)$ and for males was $42.8 \mathrm{ft}(\mathrm{SD}=2.32 \mathrm{ft}$, range $=38-$ $46 \mathrm{ft}, n=10)$.

Stomach contents were recorded for all 26 sei whales (Table 6); four (15.4\%) were empty. Plankton was the dominant prey item among the others, found in 16 of the 22 animals $(72.7 \%)$.

\section{Blue Whales}

Only three blue whales were taken, all in July (two in 1919 and one in 1924). Data were recorded for only one of these animals, a $72-\mathrm{ft}$ female whose stomach contained shrimp.

\section{SPERM W HALES}

Twelve sperm whales (Physeter macrocephalus) were taken, seven by Moss Landing and five by Trinidad. Catches were distributed across the year (Table 8). Sex was recorded for eight whales, of which all but one were male. The sole female was caught in October 1925 from Trinidad; however, the recorded length of $58 \mathrm{ft}$ suggests that either the sex determination or the length measurement of this whale was incorrect (since the stomach contained "octopus," we assume that the species designation was reliable). The lengths of the seven males were reported at $46,52,53,56,57,58$, and 61 feet. One of eight examined stomachs was empty; five contained "octopus," one sardines, and one a combination of "shark and squid."

\section{Gray WhaLES}

Seven gray whales were killed, all but one from Moss Landing. Six were taken in January; the other was a 38-ft male killed in July 1926 (Table 8). All but one of the seven whales were male. Lengths of the six males were reported as $33,37,38,38,39$, and $42 \mathrm{ft}$. The female was $45 \mathrm{ft}$ long. Stomach contents were recorded for five whales, of which four were empty; the remaining animal was the male caught in July, which had been feeding on shrimp. The latter animal is described by Howell and Huey (1930), who reported the prey as Eupbausia pacifica. 


\section{OTHER Species}

The sole northern right whale (Eubalaena glacialis) was a $40-\mathrm{ft}$ female taken in the vicinity of the Farallon Islands on 9 April 1924 and processed at Moss Landing; its stomach was empty. The single Baird's beaked whale (Berardius bairdi, listed as a "bottlenose whale") was a 37-ft male killed in Monterey Bay on 1 October 1920; the stomach contained sardines.

\section{Discussion}

\section{Humpback Whales}

Population identity and impact of the catches - It is clear from the diminishing catches manifest by 1925 that whaling at Moss Landing and Trinidad had greatly depleted the population of humpback whales that summered in local waters. In addition, several other whaling operations of various types took humpbacks off the west coast of the continent during the same period. The most important was a shore station at Bay City, Washington, established by the American Pacific Whaling Company in 1911. Bay City continued operating until 1925 and during this period hunted whales (primarily humpbacks) from Vancouver Island to southern Oregon, although the majority of animals were killed south of Cape Flattery along the Washington coast (Scheffer and Slipp 1948). Five other shore stations in British Columbia (on Vancouver Island and in the Queen Charlotte Islands) operated at various times from 1905 to 1943 (Rice 1978; Rice, personal communication). In 1921 the schooner Carolyn Frances whaled from Mexico to Alaska, following migratory routes and killing 107 humpbacks and 37 gray whales; the locations of the humpback catches are unclear (Tønnessen and Johnsen 1982). Finally, whaling was conducted by three factory ships based in Bahía Magdalena in Baja California at various times between 1924 and 1929 (Rice 1978, Tønnessen and Johnsen 1982). Humpback whales were taken together with other species by all of these operations; catches of humpbacks by the various west coast and Alaskan operations between 1919 and 1926 are summarized in Table 9. During this period, a total of 2,473 humpbacks were taken by the three shore stations at Moss Landing, Trinidad, and Bay City; the latter station took an additional 1,331 humpbacks between 1911 and 1918 (Scheffer and Slipp 1948).

Assessing the combined impact of these takes depends in part upon a knowledge of humpback whale population structure in the eastern North $\mathrm{Pa}$ cific; specifically, whether the humpbacks that feed off California can be considered a separate stock from those observed farther north. We know nothing of the situation in the 1920s; however, the present-day structure is reasonably well known as a result of long-term studies of identified individuals and is summarized by Calambokidis et al. (1996). Photographic matches have shown a high rate of exchange between California, Oregon, and Washington, minimal exchange between California and British Columbia, and no exchange between California and any area of Alaska. Calambokidis et al. (1996) concluded that the California-Oregon-Washington region hosts a single intermixing feeding 
Table 9. Total humpback whale catches from West Coast and Alaskan whaling, 1919-1926. Locations of catches by the schooner Carolyn Frances are unknown.

\begin{tabular}{rcrrrrrrrr}
\hline \hline Year & $\begin{array}{c}\text { Moss } \\
\text { Landing }\end{array}$ & $\begin{array}{c}\text { Trini- } \\
\text { dad }\end{array}$ & Bay City & $\begin{array}{c}\text { Brit } \\
\text { Col }\end{array}$ & $\begin{array}{c}\text { Carolyn } \\
\text { Frances }\end{array}$ & Alaska & Baja & Total \\
\hline 1919 & 225 & & 122 & 65 & & 132 & & 544 \\
1920 & 338 & 47 & 138 & 98 & & 75 & & 696 \\
1921 & 122 & & & & 107 & 75 & & 304 \\
1922 & 154 & 348 & 124 & 50 & & 95 & & 771 \\
1923 & & 376 & 99 & 78 & & 155 & & 708 \\
1924 & & 121 & 98 & 47 & & 71 & & 337 \\
1925 & 76 & 43 & 21 & 40 & & 208 & 403 & 791 \\
1926 & & 21 & & 25 & & 388 & 499 & 933 \\
Total & 915 & 956 & 602 & 403 & 107 & 1,199 & 902 & 5,084 \\
\hline
\end{tabular}

aggregation with limited exchange with other areas (although they also suggest that some of the whales observed off California between February and April may be animals migrating from Mexico to Alaska or British Columbia). This view of humpback whale population structure in high latitudes is broadly consistent with work conducted in the North $\Lambda$ tlantic (Katona and Beard 1991) and also with the results of mitochondrial DNA analysis of North Pacific samples (Baker et al. 1994). Consequently, it seems reasonable to conclude that a similar situation prevailed in the 1920s. Thus, it is likely that the catches off California and Washington depleted a single population rather than two discrete feeding stocks, but that the animals killed off Alaska at this time were for the most part not from this same population. This is supported by the fact that catches of humpbacks fell off sharply in both California and Washington at the same time (1925), a decline that was not manifest off Alaska. Scheffer and Slipp (1948) attributed the decline and closure of the Bay City whaling station to a depletion of the population, notably by the two California stations and by Norwegian factory-ship whaling off Baja California. However, they also suggested that this situation was exacerbated by Alaskan catches, a view which seems largely untenable in light of the above.

Today, while some humpback whales from the California/Washington population are known to migrate to central America (Steiget et al. 1991.), the primary migratory destination is Mexican waters (Urbán and Aguayo 1987, Calambokidis et al. 1989). However, photographic match rates and the large number of whales identified off Mexico (relative to the current estimate of abundance for the California stock) strongly suggest that these mating and calving grounds are also used by many humpbacks from other feeding areas (Calambokidis, personal communication). This idea is consistent with the 1920s whaling data from Baja California, where 902 humpbacks were taken in Bahía Magdalena by floating factory operations between late 1924 and 1926 (Rice 1978). That a large number of humpbacks were available off Baja California at a time when catches off California and Washington were in marked 
decline supports the belief that Mexican waters were host to whales from other feeding stocks which were either unexploited or less depleted.

Population status - The high number of humpback whale catches from California, and the predominance of big animals in the records summarized here, suggests that the population was large and healthy at the onset of this period of whaling. If the length frequencies derived from the $\log$ are accurate to within a few feet, the whales in this catch were, on average, larger than those reported from the Ryukyuan Islands in the North Pacific: Nishiwaki (1959) gave mean lengths of $40.8 \mathrm{ft}$ and $39.6 \mathrm{ft}$ for females and males, respectively, from a sample of 217 animals taken in 1959. All humpbacks in the Ryukyuan catch were more than $31 \mathrm{ft}$ in length; the equivalent means for animals of 32 $\mathrm{ft}$ or more in the California sample are $44.9 \mathrm{ft}$ (females) and $43.0 \mathrm{ft}$ (males). The California catches, unlike those from the Ryukyu Islands, included numerous animals of more than $50 \mathrm{ft}$. The mean California values are also larger than those for whales taken at Akutan, Alaska, during the period 1924-1926 (Reeves et al. 1985; mean lengths for both males and females $<38 \mathrm{ft}$ ). However, Reeves et al. (1985) also gave a mean length of $43.49 \mathrm{ft}$ (males) and $45.30 \mathrm{ft}$ (females) for humpbacks taken at Port Hobron, Alaska, in 1926, which is similar to the values reported here.

We must again pause to consider the possibility that the California length values are unreliable; however, the smaller and apparently unbiased data set from Trinidad in 1920 also contains whales of up to $57 \mathrm{ft}$, which suggests that the occurrence of many large animals in the overall catch is not a function of exaggerated estimates. Whether the maximum size given in the log (a $61-\mathrm{ft}$ female) is accurate is unknown; this is very large for a humpback whale, but the idea that an unexploited population could contain a few whales of this size is not entirely implausible. Interestingly, with the exception of 1926 (for which the sample size was only 21 animals), mean lengths did not decline over the period of whaling, as might be expected from a heavily exploited population.

It is beyond the scope of this article to provide a broad assessment of the recovery of California/Washington humpback whales from the various periods of exploitation to which they were subjected this century. However, the apparent resilience of this population is worthy of note. It is clear that these whales were repeatedly hit hard during several periods of whaling (Rice 1974, 1978), the most recent of which was off California between 1956 and 1965 , when 841 whales were killed. The figures reported here do not include a component for animals struck and lost, about which there is little information for the earlier periods of whaling. Despite this exploitation, data from both mark-recapture and line-transect surveys give estimates of abundance of approximately 600 for the present population (Barlow 1995, Calambokidis and Steiger 1995). Nonetheless, the large catches of humpbacks from the west coast in the early part of this century $(2,473$ from Trinidad, Moss Landing, and Bay City alone over a seven-year period) suggest that the pre-exploitation stock was considerably larger than the present population and, therefore, that the latter may be well below historic carrying capacity. 
Occurrence-Use of the catch data to assess the temporal occurrence of humpback whales off northern and central California is complicated by the paucity of information on effort, and we discuss the subject with that caveat in mind. The well-known seasonal migration of humpback whales between feeding grounds in temperate or polar waters and mating and calving areas in the tropics (Chittleborough 1965, Dawbin 1966) is reflected in the California data. Whales became locally abundant in spring and began to disappear from the area in late autumn as they returned to their winter mating and calving ranges, presumably in Mexican waters. The question of whether all whales undertook the migration has long been debated, and the general assumption has been that, with the possible exception of some juvenile animals, few whales remained in high latitudes during the winter. However, recent data have contradicted this view. Straley (1990) found humpbacks of all age classes in southeastern Alaska in midwinter. Brown et al. (1995) used a molecular method to determine the sex of a large number of whales migrating along the eastern Australian coast and concluded from the male-biased sex ratio that a substantial number of females do not undertake the migration every year, a contention that appears to be supported by analysis of whaling catches from that area.

The California data are interesting in this regard. Without knowledge of effort, it is impossible to assess the true local abundance of whales in midwinter, but the 49 humpbacks killed in January and February included both males and females of all size classes. However, it is not possible to determine whether these whales were overwintering in the area rather than being late migrants or early returnees (or whales migrating to Alaska, as suggested by Calambokidis et al. (1996) for the present-day population). While the percentage of whales (40.9\%) with empry stomachs at this time is higher than at any other period of the year, most of the whales concerned had been feeding. Four whales reported as $30 \mathrm{ft}$ long were killed in January. These may have been recently weaned calves that had separated from their mothers shortly before; in recent years, separation on the feeding grounds has been reported from the Gulf of Maine (Baraff and Weinrich 1993).

Whaling data on humpbacks from elsewhere (Nishiwaki 1959, Chittleborough 1965, Dawbin 1966) show a staggered migration, with newly pregnant females among the first to return from low latitudes. None of the females in the midwinter California catch were recorded as pregnant, but this may reflect the difficulty of detecting a very small fetus. Females in advanced pregnancy are also among the last to leave the feeding grounds in late autumn, and the California data are consistent with this; $8(61.5 \%)$ of 13 mature females taken in December were pregnant.

The even sex ratio observed in all months of the year is not unexpected. Similar ratios in humpback whales have been reported from both whaling data (Matthews 1937, Chittleborough 1965) and recent long-term studies of identified individuals (Glockner-Ferrari and Ferrari 1990, Clapham et al. 1995). Unlike some balaenopterids (e.g., minke whales, Balaenoptera acutorostrata; Wada 1989), humpback whalc populations exhibit no segregation by either sex or age class, and this is evident in both the even sex ratios and in the 
occurrence of animals of all sizes in the catch. It is not clear why there is a marginally significant surplus of females in the overall sample. Female humpbacks are somewhat larger than males (Nishiwaki 1959, Chittleborough 1965; Fig. 2, 3); given this, perhaps gunner selection for larger animals created a slight bias in the catch towards females.

As would be expected, the California humpbacks were in the poorest condition at the end of winter, presumably after having fasted and traveled for several weeks. Although the assessment of body condition was subjective, the observed trend from poor in March to a maximum in late autumn is consistent with seasonal differences in the oil yield from humpbacks killed off the coasts of Australia during both northward and southward migrations (see Chittleborough 1965, fig. 12).

Stomach contents_- Humpback whales are generalists in their foraging, taking small schooling fish of several species as well as euphausiids; the variety of prey reported in the stomachs of the California animals reflects this broad diet. Elsewhere, the piscine prey of this species includes capelin, Mallotus villosus (Whitehead 1981, 1983), herring (Watkins and Schevill 1979, Baker et al. 1985), mackerel, Scomber scombrus (Geraci et al. 1989), and sand lance, Ammodytes spp. (Overholtz and Nicolas 1979, Payne et al. 1986). The present data confirm the importance of anchovies to humpback whales; Rice (1963) found anchovies in $64 \%$ of 149 stomachs from humpbacks killed off California between 1959 and 1962. More significant is the predominance of sardines in the diet during the 1920s. This period pre-dates the crash of the sardine stock that occurred in this area in the early 1950s, following which anchovies increased in abundance to become the principal prey consumed by whales in the area (Rice 1977).

In some areas the primary or exclusive prey of the humpback are euphausiids of several genera, notably Euphausia, Thysanoëssa, and Meganyctiphanes (Matthews 1937; Nemoto 1957, 1959; Slijper 1962). It is likely that much of the "shrimp" recorded by the California whalers was Euphausia pacifica, which Howell and Huey (1930) describe seeing in the stomachs of whales at Trinidad in 1926 and which Rice (1963) found in the stomachs of $36 \%$ of the humpbacks taken off California in later years. However, it is likely that "shrimp" sometimes also refers to Tbysanoëssa spinifera, which appears to be the primary euphausiid taken by baleen whales in this region today (Schoenherr 1991).

Interannual variations in the composition of humpback whale prey have been reported from other areas (Payne et al. 1986, 1990), and the occurrence of such variation in the California data is therefore not unexpected. However, the observed variability in stomach contents in part reflects a regional difference in prey type between the two stations. Exploitation of krill appeared to be largely restricted to whales within the area of operation of Trinidad; of 664 records of krill in the stomachs of humpback, fin, and sei whales, only 19 (2.9\%) were from Moss Landing (see Fig. 4). Thus, krill was absent in 1921 when Trinidad did not operate, but was abundant in 1923 when Trinidad was (at least according to the $\log$ ) the sole open station. It is not clear whether the sharp regional difference in the frequency with which krill (in particular) 
was found reflects major differences in the occurrence of euphausiids in the two areas, or a preference on the part of humpback and other whales for one prey type over another when both are equally available.

More noteworthy is the variation among years in the percentage of stomachs found to be empty, which varied from $2.7 \%$ in 1923 to $34.3 \%$ in 1921 . 'There is no apparent correlation berween the whaling data and the incidence of El Niño Southern Oscillation (ENSO) events; among the seven years for which stomach content information was recorded (1920-1926), El Niños occurred in only 1924 and 1926, years which show no pattern in either prey type or frequency. Ilowever, the effects of ENSO events on marine productivity (and thus on whales) are complex, and the absence of relevant oceanographic data from the period in question precludes further investigation.

Reproduction-In the whaling data of later years, the true pregnancy rare for a population was expected to be below the apparent rate because of a prohibition on the taking of lactating females, a small percentage of which would be pregnant. The difference between apparent and true values in the present data is likely to be smaller, because females with calves were taken by both stations. However, the number of lactating animals (38) in the sample of 374 mature females used here is relatively small, suggesting either that whalers sometimes spared this class of animals, or that calves were not always recorded. In light of this uncertainty, and of the probability that many fetuses were not tecorded, it is impossible to determine the true pregnancy rate from the data. The appatent value given here (0.46) for prevalence of pregnancy in the total sample of mature females is similar to annual pregnancy rates reported for this species from other whaling data. These include 0.37 from western Australia (Chirtleborough 1965), 0.40 from the Ryukyu Islands (Nishiwaki 1959), 0.43 from the Pacific Northwest (Rice 1963), and 0.54 from a sample of 13 animals taken for scientific research in the western North Atlantic (Mitchell 1974). The California value is also similar to measures of "calves per mature female per year" (CMFY) calculated from long-term sighting data, including a 9-yr mean of 0.41 (range: 0.24-0.50) for the Gulf of Maine (Clapham and Mayo 1990). Baker et al. (1987) give a figure of 0.37 CMFY for southeastern Alaska, although this may represent an underestimate due to probable inclusion of some immature females in the data on which the calculation was based. The present humpback population off California appears to possess a low reproductive rate relative to that in other studied areas (Steiger and Calambokidis, unpublished data), for reasons which are not clear.

\section{Other Species}

Fin whales-As would be expected for a species that supposedly migrates to warm waters during the winter, fin whales were caught off Moss Landing and Trinidad primarily during the summer months. However, as with humpbacks, it is not clear whether the fin whales caught in midwinter were late migrants or animals which remained on the feeding grounds during this time.

The maximum lengths recorded for fin whales (an $81-\mathrm{ft}$ female and a $75-\mathrm{ft}$ 
male) are larger than the respective $75-\mathrm{ft}$ and $68-\mathrm{ft}$ maxima given by Rice (personal communication) from central California in later years. However, the Moss Landing and Trinidad values are within the known range for this species, and we should again bear in mind that the whalers were dealing with a pristine population.

The even sex ratio observed in the fin whale catch is similar to that reported from whaling data elsewhere (reviewed in Gambell 1985). The polymodal distribution of lengths (Fig. 6) suggests that animals of all age classes were present in the region. There was no difference in length distribution or sex composition of the catch between the two stations. Thus, there is no evidence in these data for the apparent spatial segregation by length or sex that has been suggested for fin whale populations in other areas (Mackintosh 1965, Mitchell 1974, Rörvik et al. 1976). However, the virtual absence of calves in the data (only one female was recorded as being accompanied by a calf) is noteworthy, unless it indicates only that whalers frequently failed to note calves when mothers were taken. Preferential use of particular areas by lactating females in an otherwise mixed population has been suggested for fin whales in the Gulf of Maine (Agler et al. 1993).

The primary prey of fin whales is generally considered to be schooling fish or euphausiids (Mitchell 1975, Kawamura 1994), and these items indeed made up the majority of fin whale stomach contents in the California catch. Rice (1963) examined 261 fin whale stomachs off California in the period 19591962 and found that $90 \%$ contained E. pacifica, with anchovies in the remainder. In addition, Howell and Huey (1930) noted that finbacks off Trinidad in 1926 were feeding extensively on this species. As noted above, it seems likely that the records of "plankton" (in more than a fifth of the fin whales caught) refer to euphausiids. However, we cannot entirely reject the alternative idea that these animals had been eating copepods. Nemoto (1959) reported that copepods (in this case Calanus cristatus, recently renamed Nencalanus cristatus) were a major prey item for fin whales in the Aleutians.

All of the caveats noted above for humpback whale reproductive data apply cqually to fin whales. The calculated value for apparent prevalence of pregnancy among mature females $(0.44)$ is broadly similar to annual pregnancy rates reported from whaling data (Mitchell 1974, Haug 1981, Martin 1982), and from a long-term study in the Gulf of Maine (Agler et al. 1993).

Sei whales - The occurrence of numerous sei whales off northern California in August/September 1926, when 25 were caught, is interesting, since this species is rarely observed there today. Sei whales are known for sudden influxes into feeding areas followed by disappearance for sometimes decades (Horwood 1987, Schilling et al. 1992), and it is possible that the 1926 catch reflects such an invasion. However, it is just as likely that sei whales were present but ignored by whalers until after the depletion of the humpback population, a situation which was repeated in the region after 1959 (Rice 1977). With no information on effort, we are unable to choose between these two hypotheses.

Assuming that we are correct in our interpretation of the term "plankton" from the $\log$ (see above), the sei whales in the catch had fed primarily on 
euphausiids and secondarily on sardines. These two organisms were also the major prey of sei whales off California in the 1960s (Rice 1977).

Blue whales - The virtual absence of blue whales from the catch (only three were recorded) raises the question of whether this species was uncommon in coastal California waters at the time. If so, this would be a sharp contrast to the situation today, when blue whales are among the most abundant large cetaceans in the region, with a population that is currently estimated at approximately two thousand (Barlow 1995, Calambokidis and Steiger 1995). It is difficult to believe that whalers would ignore the largest of all whales, especially while taking the comparably sized fin whale. Indeed, a popular article on the Moss Landing operation (Clark 1927, p. 384) notes that the "sulphur-bottom is the noblest game of modern whaling," and records the taking of a 72-ft blue whale (possibly the female of this length recorded in the log from 24 July 1924). Once again, however, lack of data on effort and the whalers' intent rules out further discussion.

Other species-Little can be said about the occurrence or biology of the other species in the catch. The sole right whale is of interest because of the rarity of this species in the eastern North Pacific in modern times; the details of this particular catch were reported previously by Gilmore (1956). All but one of the seven gray whales were presumably taken on their well-known migration between Alaska and calving lagoons in Baja California. The remaining animal, a male, represents an interesting exception in that it was killed in July and had been feeding on Euphausia pacifica. Howell and Huey (1930), in describing this whale and its prey, note that it was killed close to shore and "almost on the rocks" near Crescent City, and that it had been in the company of four others. Summer residency and feeding by gray whales along the northern coast of California is not uncommonly reported (Gilmore 1960, Rice 1963, Nerini 1984, Mallonée 1991, Avery and Hawkinson 1992).

\section{Data Archiving}

Computerized forms of the data from the CSPC $\log$ and the Trinidad 1922 station log have been archived at both the Southwest Fisheries Science Center (P. O. Box 271, La Jolla, CA 92038, U.S.A.) and the International Whaling Commission (the Red House, Station Road, Histon, Cambridge CB4 4NP, England).

\section{ACKNOWLEDGMENTS}

Careful reviews by Dale Rice, Gretchen Steiger, and Jay Barlow significantly improved this paper, and we thank them all for their efforts. Thanks are also due to Kendal Willison for her meticulous data entry.

\section{Literature Cited}

Avery, W. E., AND C. Hawkinson. 1992. Gray whale feeding in a northern California estuary. Northwest Science 66:199-203. 
Agler, B. A., R. L. Schooley, S. E. Frohock, S. K. Katona and I. E. Seipt. 1993. Reproduction of photographically identified fin whales, Balaenoptera physalus, from the Gulf of Maine. Journal of Mammalogy 74:577-587.

Anon. 1926. Hvalfangsten paa Pacifickysten 1925. Norsk Hvalfangst-Tidende 15:42.

Baker, C. S., L. M. Herman, $\Lambda$. Perry, W. S. Lawton, J. M. Straley and J. H. Straley. 1985. Population characteristics and migration of summer and late season humpback whales (Megaptera novaeangliae) in southeastern Alaska. Marine Mammal Science 1:304-323.

Baker, C. S., A. Perry and L. M. Herman. 1987. Reproductive histories of female humpback whales, Megaptera novaeangliae, in the North Pacific. Marine Ecology Progress Series 41:103-114.

Baker, C. S., R. W. Shade, J. L. Bannister, R. B. Abernethy, M. T. Weinrich, J. Lien, J. Urban, P. Corkeron, J. Calambokidis, O. Vasquez and S. R. Palumbi. 1994. Hierarchical structure of mitochondrial DNA gene flow among humpback whales, Megaptera novaeangliae, worldwide. Molecular Ecology 3:313-327.

BARAFF, L. S., AND M. T. WeINRICH. 1993. Separation of humpback whale mothers and calves on a feeding ground in early autumn. Marine Mammal Science 9:431434.

Barlow, J. 1995. The abundance of cetaceans in California waters. Part I: Ship surveys in summer and fall 1991. Fishery Bulletin, U.S. 93:1-14.

Brown, M. R., P. J. Corkeron, P. T. Hale, K. W. Schultz and M. M. Bryden. 1995. Evidence for a sex-segregated migration in the humpback whale (Megaptera novaeangliae). Proceedings of the Royal Society of London, Part B 259:229-234.

Cat.ambokinis, J., and G. H. Strigrr. 1995. Population estimates of humphack and blue whales made through photo-identification from 1993 surveys off California. Final report to the Southwest Fisheries Science Center, La Jolla, CA 92038.31 pp.

Calambokidis, J., G. H. Steiger, J. C. Cubbage, K. C. Balcomb and P. Bloedel. 1989. Biology of humpback whales in the Gulf of the Farallones. Final report to Gulf of the Farallones National Marine Sanctuary, San Francisco. Available from Cascadia Research, 2181/2 West 4th Avenue, Olympia, WA. 93 pp.

Calambokidis, J., G. H. Steiger, J. R. Evenson, K. R. Flynn, K. C. Balcomb, D. Caridge, J. M. Straley, C. S.Baker, O. von Ziegesar, M. E. Dahlheim, J. M. Waite, J. D. Darling, G. Ellis and G. A. Green. 1996. Interchange and isolation of kumplack whales off California and other North Pacific feeding grounds. Marine Mammal Science 12:215-226.

Chirtleborough, R. G. 1965. Dynamics of two populations of the humpback whale, Megaptera novaeangliae (Borowski). Australian Journal of Marine and Freshwater Research 16:33-128.

Clapham, P. J., AND C. A. Mayo. 1990. Reproduction of humpback whales, Megaptera novaeangliae, observed in the Gulf of Maine. Report of the International Whaling Commission (Special Issue 12):171-175.

Clapham, P. J., M. C. Bérubé and D. K. Mattila. 1995. Sex ratio of the Gulf of Maine humpback whale population. Marine Mammal Science 11:227-231.

Clark, F. S. 1927. Whaling out of the Golden Gate. Scientific American, June:82384.

DAwBIN, W. H. 1966. The seasonal migratory cycle of humpback whales. Pages $145-$ 170 in K. S. Norris, ed. Whales, dolphins and porpoises. University of California Press, Berkeley, CA.

Gambell, R. 1985. Fin whale, Balaenoptera pbysalus (Linnaeus, 1758). Pages 171-192 in S. H. Ridgway and R. Harrison, eds. Handbook of marine mammals Vol. 3: The sirenians and baleen whales. Academic Press, London.

Geraci, J. R., D. M. Anderson, R. J. Timperi, D. J. St. Aubin, G. A. Early, J. H. PRESCOTt AND C. A. MAYo. 1989. Humpback whales (Megaptera novaeangliae) fatally poisoned by dinoflagellate toxins. Canadian Journal of Fisheries and Aquatic Science 46:1895-1898. 
Gitmore, R. M. 1956. Rare right whale visits California. Pacific Discovery 9:20-25.

Gilmore, R. M. 1960. A census of the California gray whale. U.S. Fish and Wildlife Service, Special Scientific Report, Fisheries No. 342:1-30.

Glockner-Ferrari, D. A., and M. J. Ferrari. 1990. Reproduction in the humpback whale (Megaptera novaeangliae) in Hawaiian waters, 1975-1988: The life history, reproductive rates and behaviour of known individuals identified through surface and underwater photography. Report of the International Whaling Commission (Special Issue 12):161-169.

Haug, T. 1981. On some reproductive parameters in fin whales Balaenoptera physalus (L.) caught off Norway. Report of the International Whaling Commission 31: $373-378$.

Howell, A. B., And L. M. Huey. 1927. Visit to a California whaling station. Smithsonian Miscellaneous Collections 78(7):71-79.

Howell, A. B., AND L. M. Huey. 1930. Food of the gray and other whales. Journal of Mammalogy 11:321-322.

Horwood, J. W. 1987. The sei whale: Population biology, ecology and management. Croon Helm Ltd., UK.

KatONA, S. K., AND J. BEARD. 1991. Humpback whales (Megaptera novaeangliae) in the western North Atlantic Ocean. Memoirs of the Queensland Museum 30:307321.

Kawamura, A. 1994. A revicw of balcen whalc fecding in the Southern Ocean. Report of the International Whaling Commission 44:261-271.

KellogG, R. 1931. Whaling statistics from the Pacific coast of North America. Journal of Mammalogy 12:73-77.

Mackintosh, N. A. 1965. The stocks of whales. Fishing News (Books) Ltd., London.

MallonéE, J. S. 1991. Behaviour of gray whales (Eschrichtius robustus) summering off the northern California coast, from Oatrick's Point to Crescent City. Canadian Journal of Zoology 69:681-690.

Martin, A. R. 1982. Pregnancy rates of fin whales in the Icelandic catch. Report of the International Whaling Commission 32:325-329.

Matthews, L. H. 1937. The humpback whale, Megaptera nodosa. Discovery Reports $17: 7-92$.

Mrtchell, E. D. 1974. Present status of Northwest Atlantic fin and other whale species. Pages 108-169 in W. E. Schevill, ed. The whale problem. Harvard University Press, Cambridge, MA.

Mrtchell, E. D. 1975. Trophic relationships and competition for food in Northwest Atlantic whales. Proceedings of the Canadian Society of Zoology, Annual Meeting: $123-133$.

Nemoro, T. 1957. Foods of baleen whales in the northern Pacific. Scientific Reports of the Whalcs Research Institute, Tokyo 12:33-89.

Nemoto, T. 1959. Foods of baleen whales with reference to whale movements. Scientific Reports of the Whales Research Institute, Tokyo 14:149-290.

Nerini, M. 1984. A review of gray whale feeding ecology. Pages 423-450 in M. L. Jones, S. L. Swartz and S. Leatherwood, eds. The gray whale. Academic Press, Orlando, FL.

NishIwakt, M. 1959. Humphack whales in Ryukyuan waters. Scientific Reports of the Whales Research Institute, Tokyo 14:49-87.

Overholtz, W. J., and J. R. Nicolas. 1979. Apparent feeding by the fin whale, Balaenoptera physalus, and the humpback whale, Megaptera novaeangliae, on the American sandlance, Ammodytes americanus, in the Northwest Atlantic. Fishery Bulletin, U.S. 77:285-287.

Payne, P. M., J. R. Nicolas, L. O'Brien and K. D. Powers. 1986. Distribution of the humpback whale, Megaptera novaeangliae, on Georges Bank and in the Gulf of Maine in relation to densities of the sand eel, Ammodytes americanus. Fishery Bulletin, U.S. 84:271-277. 
Payne, P. M., D. N. Wiley, S. B. Young, S. Pittman, P. J. Clapham and J. W. Jossi. 1990. Recent fluctuations in the abundance of baleen whales in the southern Gulf of Maine in relation to changes in selected prey. Fishery Bulletin, U.S. 88: $687-696$

RADCLIFre, L. 1933. Economics of the whaling industry with relationship to the convention for the regulation of whaling. 73rd Congress, 2nd Session, Senate Commerce Committee. U.S. Government Printing Office, Washington DC. 79 pp.

RaLLs, K. 1976. Mammals in which females are larger than males. Quarterly Review of Biology 51:245-270.

Reeves, R. R., S. Leatherwood, S. A. Karl AND E. R. Yohe. 1985. Whaling results at Akutan (1912-39) and Port Hobron (1926-37), Alaska. Report of the International Whaling Commission 35:441-457.

RICE, D. W. 1963. Progress report on biological studies of the larger Cetacea in the waters off California. Norsk Hvalfangst-Tidende 52:181-187.

Rice, D. W. 1974. Whales and whale research in the eastern North Pacific. Pages 170-195 in W. E. Schevill, ed. The whale problem. Harvard University Press, Cambridge, MA.

RICE, D. W. 1977. Synopsis of biological data on the sei whale and Bryde's whale in the eastern North Pacific. Report of the International Whaling Commission (Special Issue 1):92-97.

RICE, D. W. 1978. The humpback whale in the North Pacific: distribution, exploitation, and numbers. Report on a workshop on problems related to humpback whales (Megaptera novaeangliae) in Hawaii, Appendix IV, pp. 29-44. Report number PB-280 794. National Technical Information Service, Springfield, VA.

Rörvik, C. J., J. Jónsson, O. A. Mathisen And Å Jonsgård. 1976. Fin whales, Balaenoptera physalus (L.), off the west coast of Iceland: distribution, segregation by length and exploitation. Rit Fiskideildar 5:1-30.

SAYERS, H. 1984. Shore whaling for gray whales along the coast of the Californias. Pages 121-157 in M. L. Jones, S. L. Swartz and S. Leatherwood, eds. The gray whale. Academic Press, Orlando, FL.

SCHEFfer, V. B., AND J. W. SLIPP. 1948. The whales and dolphins of Washington State with a key to the cetaceans of the west coast of North America. American Midland Naturalist 39:257-337.

Schilding, M., I. E. Seipt, M. T. Weinrich, S. Frohock, A. E. Kuhlberg and P. J. Clapham. 1992. Behavior of individually identified sei whales, Balaenoptera borealis, during an episodic influx into the southern Gulf of Maine in 1986. Fishery Bulletin, U.S. 90:749-755.

Schoenherr, J. R. 1991. Blue whales feeding on high concentrations of euphausiids around Monterey Submarine Canyon. Canadian Journal of Zoology 69:583-594.

Stujper, E. J. 1962. Whales. Cornell University Press, Ithaca, NY.

Starks, E. C. 1922. A history of California shore whaling. California State Fish and Game Commission, Fishery Bulletin, U.S. 6:1-38.

Steiger, G. H., J. Calambokidis, K. C. Balcomb and J. C. Cubbage. 1991. Movement of humpback whales between California and Costa Rica. Marine Mammal Science 7:306-310.

Straley, J. M. 1990. Fall and winter occurrence of humpback whales (Megaptera novaeangliae) in southeastern Alaska. Report of the International Whaling Commission (Special Issue 12):319-323.

Tønnessen, J. N., And A. O. Johnsen. 1982. The history of modern whaling. C. Hurst and Co., London.

Urbán, R. J., ANd A. Aguayo. 1987. Spatial and seasonal distribution of the humpback whale, Megaptera novaeangliae, in the Mexican Pacific. Marine Mammal Science 3:333-344.

WADA, S. 1989. Latitudinal segregation of the Okhotsk Sea-West Pacific stock of minke whales. Report of the International Whaling Commission 39:229-233. 
W AtKIns, W. A., AND W. E. Schevill. 1979. Aerial observation of feeding behavior in four baleen whales. Journal of Mammalogy 60:155-163.

Whitehead. H. P. 1981. The behaviour and ecology of Northwest Atlantic humpback whales. Ph.D. thesis. University of Cambridge, Cambridge.

Whitrhead, H. P. 1983. Structure and stability of humphark whale groups off Newfoundland. Canadian Journal of Zoology 61:1391-1397. 